
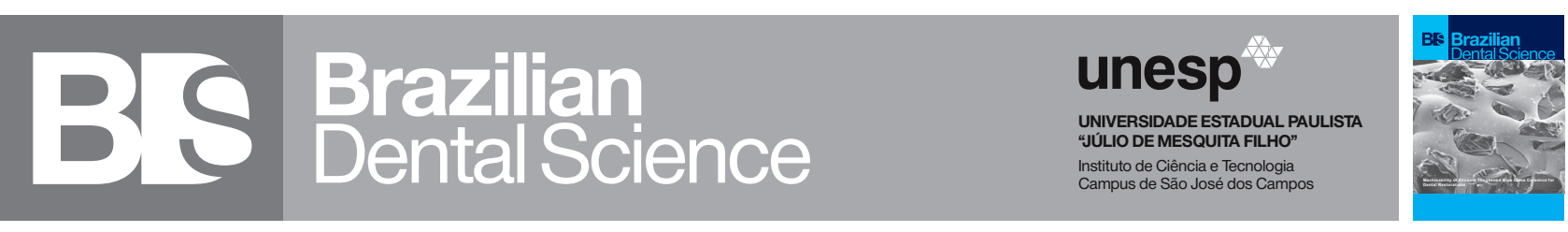

\title{
Volume measurement of mandibular teeth pulp chamber as a prediction tool of gender and ethnicity in a Brazilian population
}

Medição do volume da câmara pulpar de dentes inferiores como ferramenta de predição de gênero e etnia em uma população brasileira

Karolina Aparecida Castilho FARDIM ${ }^{1}$, Eurico Candido de OLIVEIRA JÚNIOR ${ }^{1}$, Rafael de Paula RODRIGUES ${ }^{1}$, Elaine Cristina de Carvalho Béda Correa de ARAÚJO ${ }^{1}$, João Pedro Perez GOMES ${ }^{2}$, André Luiz Ferreira COSTA ${ }^{3}$, Paulo Henrique Braz da SILVA², Sergio Lúcio Pereira de CASTRO LOPES ${ }^{1}$

1 - Post graduate Program in Oral Biopathology - Institute of Science and Technology - Paulista State University Júlio de Mesquita Filho ICT UNESP, São José dos Campos, São Paulo, Brazil.

2 - Department of Stomatology, Division of General Pathology, School of Dentistry, University of São Paulo, São Paulo, Brazil,

3 - Postgraduate Program in Dentistry, Cruzeiro do Sul University, São Paulo, São Paulo, Brazil.

\section{ABSTRACT}

Objective: Forensic dentistry has used some methods for the human identification process. However, there is a need to study characteristics that are able to perform identification more specifically, increasing accuracy. Considering the role of dental arch assessment in prediction of gender and ethnicity, the purpose of this study was to assess the volume of pulp chamber as a mean to obtain new forensic evidence. Material and methods: For this task, 1.190 cone beam computed tomography (CBCT) images were retrospectively selected and subdivided according to the population number, gender, age and ethnicity. All DICOM files were imported to the open-source software ITK-SNAP ${ }^{\circledR}$ (http://www.itksnap.org/pmwiki/pmwiki.php). The segmentation process was performed in all pulp chamber aiming to obtain pulp tissue's volume. Results: As a result, the pulp chamber volume of mandibular canine teeth showed to be larger in white population than in non-white ( $\mathrm{P}$-value $=0.003$ ) and in male individuals in comparison with female (P-value $=0.038)$. Conclusion: These results, however, must be confirmed by future studies with a larger sample size and by the assessment of other variables, including texture analysis and density of dental tissues.

\section{KEYWORDS}

Cone beam computed tomography; Ethnicity; Forensic dentistry; Gender; Pulp chamber volume; Volumetric assessment.

\section{RESUMO}

Objetivo: A odontologia forense tem usado alguns métodos para o processo de identificação humana. Porém, há a necessidade de estudar características que consigam de forma mais específica realizar a identificação aumentando a precisão. Considerando o papel da avaliação da arcada dentária na predição de gênero e etnia, o objetivo deste estudo foi avaliar o volume da câmara pulpar mandibular como meio de obtenção de novas evidências periciais. Material e métodos: Foram selecionadas 1.190 imagens de tomografia computadorizada de feixe cônico (TCFC) e subdivididas de acordo com o número da população, sexo, idade e etnia. Todos os arquivos em formato DICOM foram importados para o software de código aberto ITK-SNAP $^{\circledR}$ (http://www.itksnap.org/pmwiki/pmwiki. php) onde o processo de segmentação foi realizado em todas as câmaras pulpares visando a obtenção da volumetria. Resultados: Como resultado, o volume da câmara pulpar dos caninos inferiores mostrou-se maior na população branca do que na não branca (P-valor = 0,003), no sexo masculino em comparação ao feminino (P-valor $=0,038)$. Conclusão: Esses resultados, entretanto, devem ser confirmados por estudos futuros com maior tamanho amostral e pela avaliação de outras variáveis, incluindo análise de textura e densidade dos tecidos dentários.

\section{PALAVRAS-CHAVE}

Tomografia computadorizada de feixe cônico; Etnia; Odontologia forense; Gênero; Volume da câmara pulpar; Avaliação volumétrica. 


\section{INTRODUCTION}

$\mathrm{T}$ he criminality as a cause of death is an extremely worrying issue, reason why new investigation methods must be employed aiming to increase accuracy in identifying deceased individuals. Within this context, forensic dentistry and forensic investigation methods should be further studied and elucidated $[1,2]$.

The characterization of gender prediction (GP) is widely known over the world, yet there are few odontometric studies on gender differentiation and ethnicity estimates (EE) of individuals. The teeth are considered a useful complement for GP, especially considering their resistance and preservation capacity concerning postmortem decomposition. The GP according to the size is variable in different regions of the world, and investigators have advocated the need to use specific data for each population [35].

The deposition of secondary dentin is a significant predictor of dental age; thus, alterations in the pulp volume of intact teeth are considered a predictor able to estimate the CA of the subjects [5-7]. Some investigators have attempted to establish an association between the proportion of pulp chamber area and the tooth measurement via dental radiography to obtain chronological age (CA). Considering all advantages regarding three-dimensional (3D) volume methods in forensics, 3D imaging methods of extracted teeth may help to establish a more accurate association between tooth volume and its corresponding pulp chamber [8].

Some imaging techniques can accurately assess the volume of teeth, as well as the pulp chamber and root canals, including the conebeam computed tomography (CBCT). The use of CBCT in Dentistry may reduce the clinical time while presenting the same accuracy of methods routinely employed so far in Forensic Dentistry for human identification. It may be possible to replace the current measurements methods for another based on volume features obtained from computed tomography (CT) scan [9-10].

This study assessed the value of pulp chamber volume as a forensic tool for human identification.

\section{MATERIAL AND METHODS}

This research was conducted in accordance with the ethical principles and received approval from the Institutional Review Board of the São Paulo State University (UNESP) according to protocol number 56449916.5.0000.0077.

From medical files of dental radiology clinics, a total of 1.190 CBCT examinations were selected from the five Brazilian geographical regions (North, Northeast, Central West, Southeast, and South), and subdivided according to the population number, gender, age and ethnicity in each region (Table I). The sample was divided into 09 age groups $(20-24$; 24-29; 30-34; 35-39; 40-44; 45-49; 50-54; 5559 ; 60-64 years). The division of the groups was based on data obtained from the Brazilian Institute of Statistical Geography (IBGE), aiming to enhance the reliability of the Brazilian population representation. The CBCT images were obtained from I-CAT Next Generation (Imaging Sciences International, HA, PA, EUA).

Table I - Description of materials

\begin{tabular}{|c|ccccc|}
$\begin{array}{c}\text { Territorial } \\
\text { Divisions }\end{array}$ & Population & \multicolumn{2}{c}{ Gender } & \multicolumn{2}{c|}{ Ethnicity } \\
\cline { 3 - 6 } & & Male & Female & White & Non-white \\
\hline Midwest & 84 & 42 & 42 & 36 & 48 \\
\hline Northeast & 316 & 155 & 161 & 97 & 219 \\
\hline North & 90 & 45 & 45 & 22 & 68 \\
\hline Southeast & 534 & 262 & 272 & 294 & 240 \\
\hline South & 166 & 80 & 86 & 129 & 37 \\
\hline Total & $\mathbf{1 1 9 0}$ & $\mathbf{5 8 4}$ & $\mathbf{6 0 6}$ & $\mathbf{5 7 8}$ & $\mathbf{6 1 2}$ \\
\hline
\end{tabular}


As inclusion criteria, CBCT scans were selected from patients of both genders, of Brazilian nationality, from the five Brazilian regions, ranging from 20 to 65 years old, presenting good image quality and including the regions of interest (described below). The images were acquired with voxel of 0.25 $\mathrm{mm}$, essentially presenting one mandibular canine, one mandibular first premolar, and one mandibular molar, without coronal destructions and/or restorations with pulp chamber involvement. The study excluded Scans with low-quality images, images with absence of the assessed teeth or with presence of restorations or coronal destructions impairing the pulp spaces, as well as endodontic treatment and associated periapical lesions.

\section{Software}

Volume assessment using ITK-SNAP ${ }^{\circledR}$

All images in DICOM format were imported to the open-source software ITKSNAP $^{\circledR} 2.4$ (http://www.itksnap.org/pmwiki/ pmwiki.php). The software tool used to delineate the region of interest (ROI), isolating the teeth to be investigated - mandibular canine, mandibular first premolar, and mandibular first molar - one at a time, using the multiplanar reconstruction (MPR) axial, coronal and sagittal planes (Figure 1). A dentomaxillofacial radiologist with 10 years of experience assessed the images.

The coronal portion was initially isolated for pulp chamber segmentation, taking as reference the cementoenamel junction (for canines) and $1.0 \mathrm{~mm}$ below the pulp chamber floor (for premolars and molars). After completion of the segmentation process, the software generated a three-dimensional model (3D) and a table exhibiting the volume of this structure in $\mathrm{mm}^{3}$, which were tabulated (Figure 2).
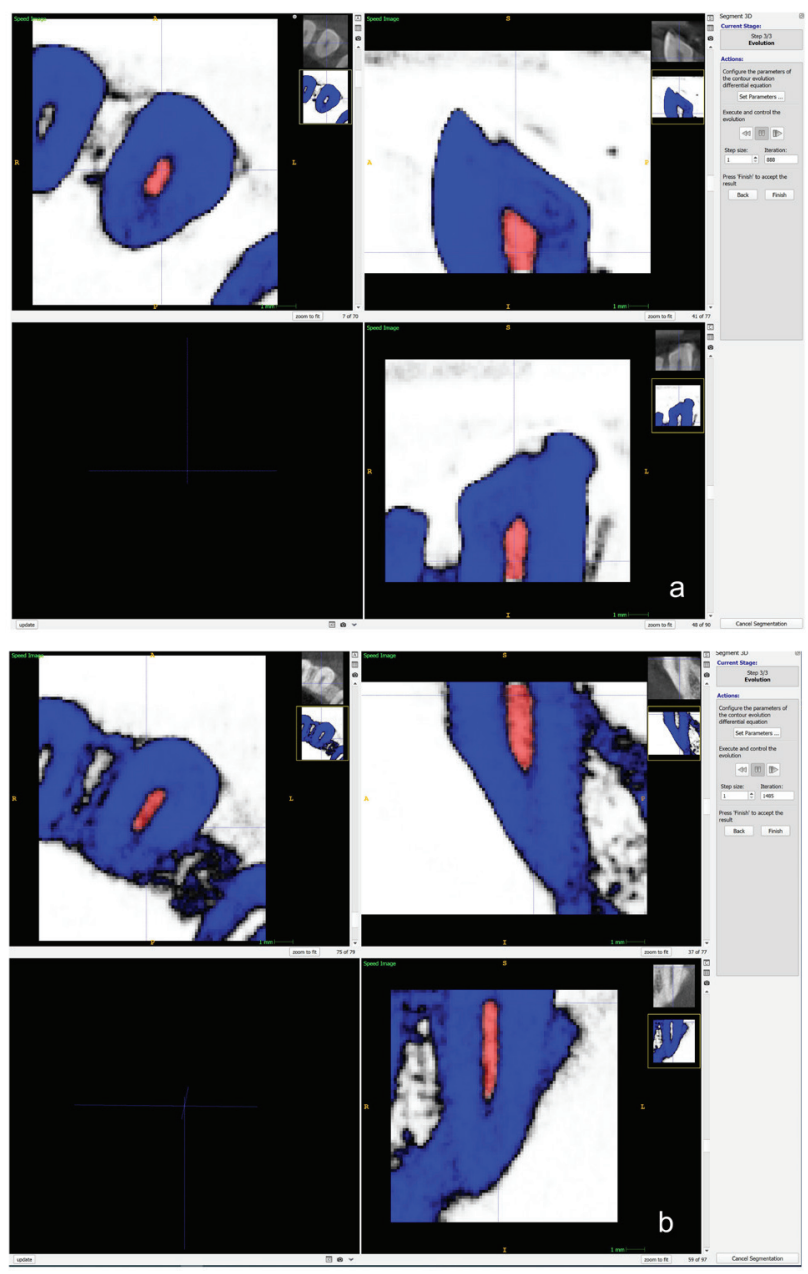

Figure 1 - Example of segmentation process by the software ITK-SNAP: (a) filling of structure (Canine pulp chamber) via segmentation; (b) filling of structure (canine root canal) via segmentation.

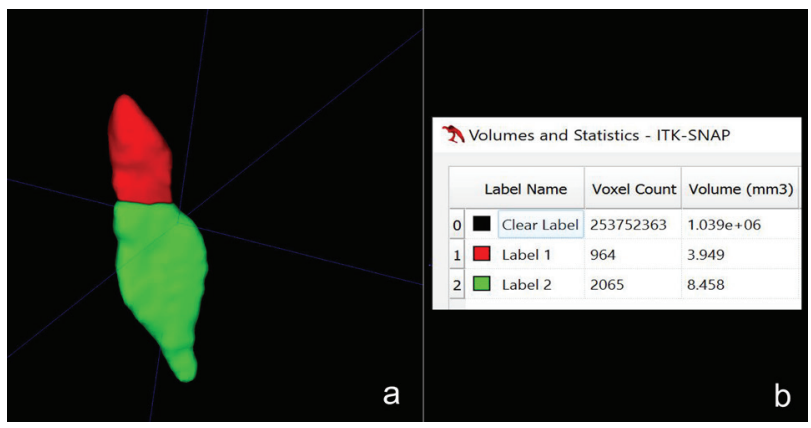

Figure 2 - Results of segmentation process by the ITK-SNAP 2.4: (a) Three-dimensional (3D) characteristics of canine pulp chamber and root canals after segmentation process. (b) volumetric data corresponding to segmented surface in axial, coronal and sagittal image slices. 


\section{Statistical analysis}

Descriptive analysis of the outcomes was performed according to gender, age-range, and ethnicity, for the measurement methods.

The numerical variables were described as means, standard deviations, medians, minimum, and maximum values. The categorical variables were described as absolute frequencies and percentages.

Numerical variables presenting normal distribution were analyzed by the Student's T-test to compare the means of groups. When the variable distribution was asymmetric, the medians were compared by the Mann-Whitney test.

\section{RESULTS}

The sample comprised subjects with a mean age of 38.4 years, ranging from 20 to 64 years, mostly females (51.2\%) of non-white ethnicity (51.5\%). Table II presents the pulp chamber volumes of the canine and root canal, according to gender. The mean and median values of the canine pulp chamber were larger for males compared to females individuals (P-value $=0.038$ ). Concerning ethnicity, significant differences were also observed for the mandibular canine pulp chamber. Non-white individuals presented significantly smaller values for volume than white individuals (P-value $=0.003$ ) (Table III). No significant differences were found regarding pulp chamber volume assessment of mandibular molars and pre-molars.
Table II - Pulp chamber and root canal volumes measured by ITK-Snap software according to gender

\begin{tabular}{|c|c|c|c|c|}
\hline \multirow{2}{*}{$\begin{array}{c}\text { Variables } \\
\text { measured by ITK- } \\
\text { Snap }\end{array}$} & \multicolumn{2}{|c|}{ Gender } & \multirow[b]{2}{*}{ Total $(n=1190)$} & \multirow[b]{2}{*}{ P-value } \\
\hline & $\begin{array}{l}\text { Female } \\
(n=609)\end{array}$ & $\begin{array}{c}\text { Male } \\
(n=581)\end{array}$ & & \\
\hline $\begin{array}{l}\text { Canine pulp chamber } \\
\text { Mean (SD) } \\
\text { Median [Q1; Q3] } \\
\text { Min; Max }\end{array}$ & $\begin{array}{c}3.17(1.09) \\
3.29[2.34 ; \\
3.60] \\
0.98 ; 5.80\end{array}$ & $\begin{array}{c}3.28(1.12) \\
3.40[2.40 ; \\
4.00] \\
0.98 ; 5.80\end{array}$ & $\begin{array}{c}3.22(1.11) \\
3.34[2.34 ; 4.00] \\
0.98 ; 5.80\end{array}$ & 0.038 \\
\hline $\begin{array}{l}\text { Canine rootcanal } \\
\text { Mean (DP) } \\
\text { Median [Q1;03] } \\
\text { Min; Max }\end{array}$ & $\begin{array}{c}14.17(2.78) \\
13.60[12.30 \\
16.16] \\
8.45 ; 25.67\end{array}$ & $\begin{array}{c}14.05(2.99) \\
13.50[12.04 ; \\
16.16] \\
8.45 ; 25.67\end{array}$ & $\begin{array}{c}14.11(2.88) \\
13.56[12.30 ; 16.16] \\
8.45 ; 25.67\end{array}$ & 0.327 \\
\hline $\begin{array}{l}\text { Pre-molar pulp chamber } \\
\text { Mean (SD) } \\
\text { Median [Q1;03] } \\
\text { Min; Max }\end{array}$ & $\begin{array}{c}3.41(1.19) \\
3.21[2.34 ; 4.45] \\
1.32 ; 6.01\end{array}$ & $\begin{array}{c}3.39(1.1) \\
3.31[2.34 ; 4.33] \\
1.32 ; 6.01\end{array}$ & $\begin{array}{c}3.40(1.15) \\
3,31[2.24 ; 4.34] \\
1.32 ; 6.01\end{array}$ & 0.965 \\
\hline $\begin{array}{c}\text { Pre-molar rootcanal } \\
\text { Mean (SD) } \\
\text { Median [Q1; Q3] } \\
\text { Min; Max }\end{array}$ & $\begin{array}{c}11.03(2.34) \\
11.24[10.13 ; \\
12.34] \\
2.33 ; 14.59\end{array}$ & $\begin{array}{c}10.92(2.41) \\
11.23[10.02 ; \\
12.34] \\
2.33 ; 14.59\end{array}$ & $\begin{array}{c}10.98(2.38) \\
11.23[10.09 ; 12.34] \\
2.33 ; 14.59\end{array}$ & 0.512 \\
\hline $\begin{array}{c}\text { Molar pulp chamber } \\
\text { Mean (SD) } \\
\text { Median [Q1; Q3] } \\
\text { Min; Max }\end{array}$ & $\begin{array}{c}4.13(1.01) \\
4.21[3.45 ; 4.56] \\
2.01 ; 6.44\end{array}$ & $\begin{array}{c}4.14(1.04) \\
4.21[3.45 ; 4.56] \\
2.01 ; 6.44\end{array}$ & $\begin{array}{c}4.13(1.03) \\
4.21[3.45 ; 4.56] \\
2.01 ; 6.44\end{array}$ & 0.441 \\
\hline $\begin{array}{l}\text { Molar rootcanal } \\
\text { Mean (SD) } \\
\text { Median [Q1; Q3] } \\
\text { Min; Max }\end{array}$ & $\begin{array}{c}22.14(2.3) \\
22,01[21.03 ; \\
23.08] \\
18.19 ; 34.50\end{array}$ & $\begin{array}{c}22.17(2.24) \\
22.09[21.04 ; \\
23.08] \\
18.19 ; 34.50\end{array}$ & $\begin{array}{c}22.15(2.27) \\
22.08 \text { [21.03; } \\
23.08] \\
18.19 ; 34.50\end{array}$ & 0.578 \\
\hline
\end{tabular}

Significant differences are highlighted in bold; SD - Standard deviation; $\mathrm{n}$ - Sample size.

Table III - Pulp chamber and root canal volumes measured by ITK-Snap software according to ethnicity

\begin{tabular}{|c|c|c|c|c|}
\hline \multirow{2}{*}{$\begin{array}{c}\text { Variables } \\
\text { measured by ITK- } \\
\text { Snap }\end{array}$} & \multicolumn{2}{|c|}{ Ethnicity } & \multirow[b]{2}{*}{ Total $(n=1190)$} & \multirow[b]{2}{*}{ P-value } \\
\hline & $\begin{array}{l}\text { White } \\
(n=577)\end{array}$ & $\begin{array}{c}\text { Non-white } \\
(n=613)\end{array}$ & & \\
\hline $\begin{array}{l}\text { Canine pulp chamber } \\
\text { Mean (SD) } \\
\text { Median [Q1; Q3] } \\
\text { Min; Max }\end{array}$ & $\begin{array}{c}3.31(1.09) \\
3.40[2.44 ; 4.12] \\
0.98 ; 5.80\end{array}$ & $\begin{array}{c}3.14(1.12) \\
3.22[2.34 ; \\
3.56] \\
0.98 ; 5.80\end{array}$ & $\begin{array}{c}3.22(1.11) \\
3.34[2.34 ; 4.00] \\
0.98 ; 5.80\end{array}$ & 0.003 \\
\hline $\begin{array}{l}\text { Canine rootcanal } \\
\text { Mean (SD) } \\
\text { Median [Q1; Q3] } \\
\text { Min; Max }\end{array}$ & $\begin{array}{c}14.04(3.07) \\
13.50[12.04 ; \\
16.16] \\
8.45 ; 25.67\end{array}$ & $\begin{array}{c}14.18(2.7) \\
13.56[12.30 ; \\
16.24] \\
8.45 ; 25.67\end{array}$ & $\begin{array}{c}14.11(2.88) \\
13.56[12.30 ; 16.16] \\
8.45 ; 25.67\end{array}$ & 0.166 \\
\hline $\begin{array}{l}\text { Pre-molar pulp chamber } \\
\text { Mean (SD) } \\
\text { Median [Q1;03] } \\
\text { Min; Max }\end{array}$ & $\begin{array}{c}3.37(1.11) \\
3.21[2.34 ; 4.33] \\
1.32 ; 6.01\end{array}$ & $\begin{array}{c}3.42(1.18) \\
3.33[2.34 ; \\
4.45] \\
1.32 ; 6.01\end{array}$ & $\begin{array}{c}3.40(1.15) \\
3.31[2.34 ; 4.34] \\
1.32 ; 6.01\end{array}$ & 0.433 \\
\hline $\begin{array}{c}\text { Pre-molar rootcanal } \\
\text { Mean (SD) } \\
\text { Median [Q1; Q3] } \\
\text { Min; Max }\end{array}$ & $\begin{array}{c}11.05(2.36) \\
11.34[10.13 ; \\
12.34] \\
2.33 ; 14.59\end{array}$ & $\begin{array}{c}10.91(2.4) \\
11.22[10.09 \\
12.34] \\
2.33 ; 14.59\end{array}$ & $\begin{array}{c}10.98(2.38) \\
11.23[10.09 ; 12.34] \\
2.33 ; 14.59\end{array}$ & 0.205 \\
\hline $\begin{array}{c}\text { Molar pulp chamber } \\
\text { Mean (SD) } \\
\text { Median [Q1; Q3] } \\
\text { Min; Max }\end{array}$ & $\begin{array}{c}4.14(1) \\
4.21[3.45 ; 4.56] \\
2.01 ; 6.44\end{array}$ & $\begin{array}{c}4.13(1.05) \\
4.21[3.45 ; 4.56] \\
2.01 ; 6.44\end{array}$ & $\begin{array}{c}4.13(1.03) \\
4.21[3.45 ; 4.56] \\
2.01 ; 6.44\end{array}$ & 0.641 \\
\hline $\begin{array}{l}\text { Molar rootcanal } \\
\text { Mean (SD) } \\
\text { Median [Q1; Q3] } \\
\text { Min; Max }\end{array}$ & $\begin{array}{c}22.13(2.2) \\
22.01[21.03 ; \\
23.08] \\
18.19 ; 34.50\end{array}$ & $\begin{array}{c}22.18(2.33) \\
22.12[21.03 ; \\
23.12] \\
18.19 ; 34.50\end{array}$ & $\begin{array}{c}22.15(2.27) \\
22.08 \text { [21.03; } \\
23.08] \\
18.19 ; 34.50\end{array}$ & 0.502 \\
\hline
\end{tabular}

Significant differences are highlighted in bold; SD - Standard deviation; $n$ - Sample size. 


\section{DISCUSSION}

The literature highlights the importance of human identification by different methods based on the inherent characteristics of the human skeleton. Within this context, to estimate the ethnicity in adults, the pulp chamber plays an important role due to the modifications related to ethnicity [10].

The use of CBCT allows for volumetric evaluation of the pulp chamber, thus may constituting a conservative and accurate method for a possible estimate of factors related to age, gender and ethnicity of subjects. Some studies have employed methods for calculation of pulp cavity volumes to estimate the age and gender. A previous study [8] using the ITK-SNAP evidenced that the pulp chamber volume was an accurate method for that purpose. Compared to the present study, we did not find conclusive data to indicate that the pulp chamber volume of mandibular molars and premolar could be used to pre-determine the age, ethnicity and gender of the individuals. However, the volume analysis of canine pulp chamber evidenced the possibility to predict gender and ethnicity of a Brazilian population individuals, with larger pulp chamber volumes for the white ethnicity compared to non-white and a larger volume for male than female.

The determination of ethnicity in a predominantly heterogeneous population such as Brazil's is a difficult task, especially considering the degree of miscegenation of our population. Moreover, considering this research was performed retrospectively by medical record consultation data, part of the information, especially regarding ethnicity, could have been imprecise.

\section{CONCLUSION}

Considering this study sample, the volume measurement of mandibular canine pulp chamber may be a method to suggest, together with other factors, gender and ethnicity of Brazilian individuals. However, these results must be confirmed by future studies with a larger sample size and by the assessment of other important variables regarding dental tissues, including texture analysis and density.

\section{Acknowledgements}

This work was supported by the São Paulo Research Foundation - FAPESP (grant number 2017/23928-0 / 2019/00495-6).

\section{Conflict of interest}

The authors have no proprietary, financial, or other personal interest of any nature or kind in any product, service, and/or company that is presented in this article.

\section{REFERENCES}

1. Instituto Brasileiro de Geografia e Estatística(IBGE). Censo Brasileiro de 2010. Rio de Janeiro: IBGE, 2012.

2. O'Donnell C, lino M, Mansharan K, Leditscke J, Woodford N. Contribution of postmortem multidetector CT scanning to identification of the deceased in a mass disaster: Experience gained from the 2009 Victorian bushfires. Forensic Scilnt.2011;205(1-3):15-28. doi:10.1016/j.forsciint.2010.05.026

3. Gamba TO, Alves MC, Haiter-Neto F. Analysis of sexual dimorphism by locating the mandibular canal in images of cone-beam computed tomography. Journal of Forensic Radiology and Imaging 2014;2:72-76. doi.org/10.1016/j. jofri.2013.12.007

4. Gamba T0,Alves MC, Haiter-Neto F.Mandibular sexual dimorphism analysis in CBCT scans. J Forensic Leg Med 2016;38:106-110. doi:10.1016/j.jflm.2015.11.024

5. Cameriere R, De LucaS, Alemán I,Ferrante L, Cingolani M. Age estimation by pulp/tooth ratio in lower premolars by orthopantomography. Forensic Sci Int. 2012;214(1-3):105-12. doi: 10.1016/j.forsciint.2011.07.028.

6. Star H, Thevissen P, Jacobs R, Fieuws S, Solheim T, Willems G. Human dental age estimation by calculation of pulp-tooth volume ratios yielded on clinically acquired cone beam computed tomography images of monoradicular teeth. J Forensic Sci. 2011;56:77-82. doi: 10.1111/.j.1556-4029.2010.01633.x.

7. Zhi-pu Ge, Pan Yang, Gang Li, Ji-zong Zhang, Xu-chen Ma. Age estimation based on pulp cavity/chamber volume of 13 types of tooth from cone beam computed tomography images. Int J Legal Med. 2016;130:1159-1167. doi: 10.1007/s00414-016-1384-6.

8. GeZP,Ma RH, LiG, Zhang JZ, MaXC. Age estimation based on pulp chamber volume of first molars from cone-beam computed tomography images. Forensic Sci Int 2015;253:133.e1-7. doi: 10.1016/j.forsciint.2015.05.004.

9. Pinchi V,PradellaF,Buti J,Baldinotti C, Focardi M, Norelli GA. A new age estimation procedure based on the 3D CBCT study of the pulp cavity and hard tissues of the teeth for forensic purposes: A pilot study. J Forensic Leg Med. 2015;36:150-7. doi:10.1016/j.jflm.2015.09.015. 
10. Parciak EC, Ankur T Dahiya AT, AIRumaih HS, Kattadiyil MT,ZBaba NZ, Goodacre CJ. Comparison of maxillary anterior tooth width and facial dimensions of 3 ethnicities. JProsthet Dent. 20170ct;118(4):504-510. doi: 10.1016/j.prosdent.2016.10.035.

\section{Karolina Aparecida Castilho Fardim}

\section{(Corresponding address)}

Santa Clara Street, 965, Village Adyana, São José dos Campos, São Paulo, Brazil CEP: 12243-630 - São José dos Campos, SP, Brazil. 